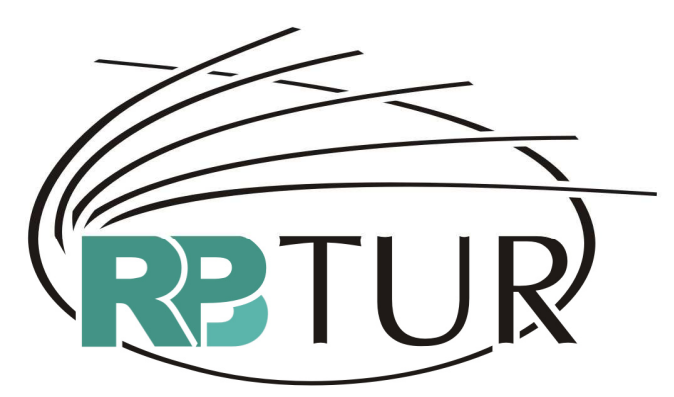

REVISTA BRASILEIRA DE PESQUISA EM TURISMO

\title{
VAI PRA ONDE?ANÁLISE DO COMPOSTO MERCADOLÓGICO DE UM DESTINO TURÍSTICO EM SANTA CATARINA
}

\author{
WHERE ARE YOU GOING? MARKETING MIX ANALYSIS OF A \\ TOURIM DESTINATION IN SANTA CATARINA STATE (BraZil)
}

\section{A DONDE VÁS? ANÁLISIS DEL COMPUESTO MARKETING DE UN DESTINO TURÍSTICO EN SANTA CATARINA (BRAZIL)}

Giancarlos Francisco Miguel $^{1}$
Ricardo Boeing da Silveira $^{2}$

Resumo: O objetivo deste estudo foi analisar as quatro variáveis (produto, preço, praça e promoção) que formam o composto de marketing de uma cidade turística no litoral de Santa Catarina, na visão dos representantes dos setores públicos e privados deste destino turístico, e não com os seus usuários. A tipologia da pesquisa utilizada foi exploratória e descritiva e o método de coleta de dados foi qualitativo através de entrevistas com roteiro semi-estruturado. Os resultados obtidos durante a investigação revelaram que este destino ainda não está estruturado o suficiente para ser considerado um produto turístico, pois atualmente passa por uma transição, mudando o foco de turismo de 'sol e mar' para o turismo de natureza e sua infraestrutura ainda necessita de investimentos, principalmente em saneamento e acessos. O elemento preço foi considerado adequado na visão dos empresários e altos demais na opinião do setor público, que percebe exageros por parte dos equipamentos turísticos. A distribuição da cidade no mercado turístico acontece principalmente de forma direta, sem a participação de intermediários (operadores e agentes turísticos) e para a promoção do destino as ferramentas utilizadas vão desde a participação em eventos turísticos, matérias e anúncios em revistas do setor e na internet. As ações são realizadas de forma pouco planejada, sem parcerias entre o trade e o Poder

\footnotetext{
1 Bacharel em Administração com Habilitação em Marketing, Especialista em Turismo: Planejamento, Gestão e Marketing, ambos pela Universidade do Vale do Itajaí. Professor no Ensino Médio Integrado a Educação Profissional - EMIEP, na rede Estadual de Educação de Santa Catarina, orientador do curso de Guia de Turismo - SENAC. E-mail: gian.miguel@univali.br

2 Doutorando em Administração pela FGV-EAESP, possui Mestrado e Graduação em Administração pela Universidade do Vale do Itajaí, especialização em Marketing pela FGV EBAPE é professor nos cursos de graduação em Administração e cursos de Pós-Graduação. Email:boeing@univali.br
} 
MIGUEL Giancarlos Francisco; SILVEIRA Ricardo Boeing da Vai pra onde? Análise do composto mercadológico de um destino turístico em Santa Catarina. Revista Brasileira de Pesquisa em Turismo. v. 2, n. 3, p. 54-89,

ISSN: $1982-6125$ nov. 2008.

Público e também sem integração com as outras variáveis do composto de marketing influenciando diretamente no desempenho deste destino no mercado turístico.

Palavras-chaves: Turismo. Composto de Marketing. Destinos Turísticos.

Abstract: This paper presents a research carried out in order to analyze the "four $\mathrm{P}$ " of the marketing mix (product, price, place and promotion) in a seaside tourism destination in Santa Catarina, through the eyes of some interviewees representing each public and private business sector. It was a qualitative research, exploratory and descriptive, and the data were obtained through semi strutured interviews. The outcome revealed that the destination is not structured yet to be considered a touristic product, because at present it is changing from sun and sea tourism to nature tourism and it lacks investments for infra structure, mainly in sewage and roads. Price was considered fair by entrepreneurs and extremely high by civil servants. Commonly the destination is placed directly in the market, with no intermediation of tour operators or retail agents. and it is promoted through tourism fairs, newspapers and journals as well as internet. Actions are generally not planned, no partnerships between trade and public sector were detected nor integration with other components of the marketing mix.

Keywords: Tourism. Marketing Mix. Tourism Destination.

Resumen: Este artículo presenta la investigación llevada a cabo para analizar los "cuatro P" del compuesto marketing (producto, precio, plaza y promoción) en un destino turístico del litoral de Santa Catarina, a través de la visión de algunos entrevistados de los sectores público y privado. Es una investigación cualitativa, exploratoria y descriptiva y los datos fueron obtenidos mediante entrevistas semiestructuradas. Se obtuvo como resultado que el destino no está estructurado aún como para ser considerado un producto turístico, porque en el momento está cambiando su perfil, de turismo sol y playa para turismo de naturaleza y le hace falta inversión para infra-estructura fundamentalmente en lo que atañe a saneamiento y accesos. El precio fue considerado justo por los empresarios pero extremadamente alto por los entrevistados pertenecientes al área pública. Normalmente este destino se comercializa directamente, sin intervención de operadores turísticos y se promueve mediante la participación en eventos de turismo, diarios, revistas e internet. Se evidenció poca planificación, pocos trabajos conjuntos entre el trade y la administración pública y ninguna integración con otros componentes del compuesto marketing.

Palabras clave: turismo. Compuesto Marketing. Destino Turístico.

\section{INTRODUÇÃO}

Para se obter sucesso em mercados cada vez mais competitivos, tornase necessário uma preparação cuidadosa de aspectos referentes ao produto ou serviço a ser oferecido a determinados grupos de consumidores. As constantes 
MIGUEL Giancarlos Francisco; SILVEIRA Ricardo Boeing da Vai pra onde? Análise do composto mercadológico de um destino turístico em Santa Catarina. Revista Brasileira de Pesquisa em Turismo. v. 2, n. 3, p. 54-89, nov. 2008.

mudanças ocorridas no mercado e no perfil dos turistas exigem desses destinos maior preocupação no planejamento de suas ações mercadológicas, a fim de evitar futuros fracassos e prejuízos incalculáveis não só financeiros, mas também de ordem social, cultural e ecológica. Após a definição de todas as características presentes no produto, é preciso organizar outros elementos importantíssimos no processo de comercialização, que tornarão conhecidos e acessíveis os produtos destinados à sua demanda potencial.

Estas variáveis que a empresa tem controle formam o que é chamado de composto de marketing ou marketing mix. Esta concepção voltada a destacar os principais elementos inseridos no processo administrativo das organizações foi elaborada por Jerome McCarthy na década de 60 e até hoje é adotada por inúmeras empresas de diversos setores nos seus planejamentos de marketing. O objetivo geral deste trabalho é analisar o composto de marketing do destino turístico de uma cidade turística no litoral de Santa Catarina.

As empresas buscam, nesse mercado extremamente competitivo, diferenciar-se na mente dos consumidores, oferecendo produtos mais eficientes, que satisfaçam as suas necessidades e desejos, a preços que este mercado esteja disposto a pagar. Sandhusen (1998) enfatiza que esta é a função do marketing, um processo que planeja as ações de uma empresa desde a concepção do produto, analisando o preço, a promoção e a praça (também denominado distribuição) até que, através de uma troca, os objetivos individuais e organizacionais sejam alcançados. Nesta mesma vertente Kotler (2000) contribui acrescentando que o marketing deve oferecer as satisfações desejadas pelo mercado, preservando o bem-estar dos clientes e da sociedade, de forma mais eficiente que os concorrentes.

Essas variáveis que são analisadas no processo de planejamento são conhecidas como os 4 Ps de marketing, que foram originalmente conceituadas nos anos 60 por Jerome McCarthy e até hoje têm uma enorme relevância no sucesso das organizações de qualquer atividade econômica (MIDDLETON, 2002). 
MIGUEL Giancarlos Francisco; SILVEIRA Ricardo Boeing da Vai pra onde? Análise do composto mercadológico de um destino turístico em Santa Catarina. Revista Brasileira de Pesquisa em Turismo. v. 2, n. 3, p. 54-89, nov. 2008

Sabendo o quanto o marketing é importante no planejamento de um produto, seja ele físico ou turístico - como é o caso deste trabalho, busca-se analisar os 4 Ps do composto de marketing que, segundo Kotler (2000), é a mistura de variáveis controláveis pela empresa, a fim de atingir seus objetivos de venda no mercado-alvo. Balanzá e Nadal (2003) complementam esta afirmação, dizendo que estas variáveis não devem ser uma simples mistura, mas sim uma combinação bem estudada destas variáveis.

\section{FUNDAMENTAÇAO TEÓRICA}

O mercado turístico vem crescendo consideravelmente nas últimas décadas e com esse crescimento surgem inúmeras ameaças e oportunidades que podem, de acordo com Vaz (1999), ser enfrentadas e aproveitadas respectivamente se as organizações turísticas souberem manejar com habilidade estes instrumentos gerenciais quem compõem o composto de marketing. O autor ainda destaca que para tirar o maior proveito desses instrumentos, deve-se conhecê-los plenamente buscando informações que possam ser analisadas e aproveitadas em futuras decisões. Diversos motivos sempre motivaram o homem a se deslocar de um lugar para outro. Na era primitiva, os indivíduos se deslocavam em busca de alimentos; na Idade Média, a religião determinava viagens e peregrinações e, na Idade Moderna, as navegações e o Grand Tour foram os principais eventos envolvendo deslocamentos por territórios distantes (OLIVEIRA, 2001; BARBOSA, 2002). Os deslocamentos realizados em busca de prazer têm sua origem na Grécia do século VIII a.C. com a realização dos jogos olímpicos, conforme apontam De La Torre (1992) e Ignarra (1999).

Mas foi a Revolução Industrial, ocorrida na Inglaterra no século XVIII, que transformou o conceito de viagens. De acordo com Dias e Aguiar (2002), através desta revolução surgiram fatores, como diminuição na jornada de trabalho, descanso nos finais de semana e férias anuais remuneradas, que passaram a contribuir significativamente para o incremento das atividades 
MIGUEL Giancarlos Francisco; SILVEIRA Ricardo Boeing da Vai pra onde? Análise do composto mercadológico de um destino turístico em Santa Catarina. Revista Brasileira de Pesquisa em Turismo. v. 2, n. 3, p. 54-89,

ISSN: $1982-6125$ nov. 2008.

ligadas ao lazer e viagens. Boyer (1996) acrescenta que neste mesmo período houve uma sensível melhora nos meios de transporte, nos serviços de alimentação e o aparecimento dos primeiros meios de hospedagem tornando, esse momento da história o início das práticas turísticas tais como são conhecidas nos dias atuais.

O fenômeno turístico começa a se firmar como atividade econômica a partir do século XIX. O aperfeiçoamento do sistema ferroviário e a utilização de navios a vapor, do automóvel e do avião (estes últimos após as duas Grandes Guerras Mundiais) como meios de transportes utilizados nas atividades turísticas contribuíram de forma decisiva para a evolução do turismo (ARENDIT, 2000; DIAS; AGUIAR, 2002; BARBOSA, 2002).

Outro fato relevante deste período relatado por Bonald (1984), Lage e Milone (1999) e Oliveira (2001) é o surgimento da primeira agência de viagens, fundada por um pastor inglês chamado Thomas Cook, que buscava a melhoria e a dinamização das viagens organizadas por ele. Segundo estes autores, Cook foi responsável pela organização completa (acomodação, transporte e atividades no destino) de uma viagem e pela criação de documentos muitos utilizados em turismo até os dias de hoje, como o voucher (espécie de recibo de pagamento) e do circular note (traveller check - cheque de viagens).

Quando se pensa em turismo, a primeira idéia que se tem é de pessoas se divertindo, passeando ou aproveitando o período de férias com amigos ou parentes em algum lugar paradisíaco (GOELDNER; RITCHIE; MCINTOSH, 2002). Para autores como Barreto (1995) e Beni (2001), o turismo teve sua origem na disposição do homem ao lazer e na maneira de utilização do tempo livre por eles. A origem do termo 'turismo', de acordo com Arthur Haulot (apud BARRETO, 1995), vem do hebraico tur, que aparece na Bíblia como sendo 'viagem de reconhecimento'. Outras formas, como tour, que significa volta em francês e se equivale a turn em inglês e tornare do latim, também são aceitas como origens deste termo (BARRETO, 1995). 
MIGUEL Giancarlos Francisco; SILVEIRA Ricardo Boeing da Vai pra onde? Análise do composto mercadológico de um destino turístico em Santa Catarina. Revista Brasileira de Pesquisa em Turismo. v. 2, n. 3, p. 54-89,

O turismo é o maior dos movimentos migratórios da história da humanidade e caracteriza-se por sua taxa de crescimento constante, como afirma Ruschmann (1999). A sua expansão está ligada diretamente ao progresso econômico, à concentração urbana, às facilidades de circulação e ao desenvolvimento dos transportes.

Mota (2001) afirma que o fenômeno turístico possui inúmeras definições e interpretações elaboradas por vários autores. A mais antiga definição de turismo foi constituída em 1910 pelo economista Hermann Von Schullard, como sendo "a soma das operações, principalmente de natureza econômica, que estão diretamente ligadas com a entrada, permanência e deslocamento de estrangeiros para dentro e fora de um país, cidade ou região" (WAHAB, 1991). Outras definições surgiram ao longo do século $X X$, as principais foram a de Hunziker e Krapf (1942), Burkart e Medlik (1981) e Mathieson e Wall (1982), declarando que o turismo é considerado um fenômeno caracterizado pelas relações produzidas no deslocamento e permanência de não residentes por um período inferior a um ano e sem atividades remuneratórias (BALANZÁ; NADAL, 2003). Esta definição é compartilhada por Castelli (1984) com a condição de que tal permanência não estabeleça nenhum vínculo permanente.

Beni (2001), aponta três tendências consolidadas sobre este assunto: econômica, técnica e a holística. A definição econômica teve como precursor o economista Harmann Van Schullen, em 1910, que foi ampliada por Robert McIntosh (1977), considerando o turismo uma atividade que atrai, transporta e aloja visitantes, sempre visando satisfazer as suas necessidades e desejos (BARROS, 2005). Pode-se perceber neste conceito que o autor tem uma visão qualitativa do turismo. Já Barreto (1995) e Cunha (1997) destacam que o capital resultante do turismo reflete na economia e que este processo é decorrente do fluxo de pessoas em diferentes lugares.

Andrade (2002) possui uma visão bem clara do papel que a atividade turística desencadeia numa região. Para o autor, uma pessoa que está fora de sua residência necessita fundamentalmente de alojamento, alimentação e de 
MIGUEL Giancarlos Francisco; SILVEIRA Ricardo Boeing da Vai pra onde? Análise do composto mercadológico de um destino turístico em Santa Catarina. Revista Brasileira de Pesquisa em Turismo. v. 2, n. 3, p. 54-89, nov. 2008.

serviços e bens que irão estimular diversos setores econômicos deste núcleo receptor.

No entender de Barreto (1996) e de Coriolano (1998), o turismo envolve os três setores da economia. O primário é representado pela alimentação, o secundário congrega toda a parte de infra-estrutura e no terciário aparecem os serviços de atendimento, muito presente no setor turístico. Eles ainda relatam que o turismo passou a ser definido como 'indústria sem chaminé', por mobilizar uma grande quantidade de serviços, levando ao consumo e desenvolvendo novas atividades. Davidson (2001) compartilha da opinião destes autores, mas acrescenta que o fenômeno turístico é mais do que um setor; é uma 'indústria' que afeta uma ampla gama de setores e não diz respeito somente a empreendimentos ou governos, mas sim a pessoas.

Para O 'Connor (2001), "o turismo é a maior indústria e um dos maiores empregadores em termos mundiais, [...] e diferentemente de muitos outros setores, deve crescer nas próximas décadas, pois o tempo destinado ao lazer está aumentando". Essa visão é compartilhada por Theobald (2001), o qual assegura que sob qualquer que seja o critério adotado, desde investimentos de capital, geração de empregos e até mesmo em arrecadação, o turismo se configura como o principal segmento econômico mundial.

Já como tendência holística Jafari (apud BENI, 2001) e De La Torre (apud BARRETO, 1995) apontam que o turismo se caracteriza pelo estudo dos turista e visitantes, da oferta turística que visa satisfazer suas necessidades e dos impactos que ambos geram sobre a área receptora. Mota (2001) acrescenta a essa definição o fato desta atividade poder gerar inter-relações de cunho ecológico tanto nos núcleos emissores como nos receptores do turismo. Outra questão que ele aborda é o reconhecimento de turistas, os indivíduos que viajam a trabalho, no intuito de participar de eventos, congressos ou feiras, aos lugares configurados como destinos turísticos. E ainda pode-se destacar a definição de Wahab (1991), que observa o turismo como uma atividade humana intencional que serve como meio de comunicação e elo entre povos dentro ou fora das fronteiras dos países. 
MIGUEL Giancarlos Francisco; SILVEIRA Ricardo Boeing da Vai pra onde? Análise do composto mercadológico de um destino turístico em Santa Catarina. Revista Brasileira de Pesquisa em Turismo. v. 2, n. 3, p. 54-89,

No entender de Luhrman e Benot (1999), atualmente o setor turístico é uma indústria capaz de dinamizar a economia em nível nacional e local, ao mesmo tempo em que pode contribuir para a harmonia e integração econômica e social de uma nação.

Tendo em vista o crescimento exponencial do setor turístico, faz-se necessário, a aplicação de técnicas administrativas no processo de planejamento turístico que visem à satisfação dos consumidores e a obtenção de lucros por parte das empresas que oferecem produtos e serviços. Tem-se aí a necessidade de implantar neste setor ações estratégicas, visando a melhorias no produto, no preço, na distribuição e na comunicação que de uma forma eficaz irão estabelecer objetivos que levarão à satisfação de todas as partes envolvidas no processo.

De modo geral, há um consenso de que o marketing e seus elementos teóricos são válidos para todos os tipos de produtos, independentemente de serem baseados em serviços ou bens físicos (MIDDLETON, 2002). Validando essa teoria, Kotler (1998) expõe que o processo de marketing é aplicável não apenas a bens e serviços, mas também a idéias, eventos, locais e pessoas. Seguindo essa corrente, Vaz (1999) declara que o marketing turístico compreende um conjunto de atividades que facilitam a realização de trocas entre os diversos agentes que atuam, direta ou indiretamente, no mercado de produtos turísticos. Nesta definição, não se evidencia diferenças entre o marketing de produtos físicos e o marketing de produtos turísticos, embora ambos em sua essência tenham características particulares. Entretanto, Balanzá (2003) cita o pensamento de Fernando Muñoz Oñate onde "o marketing turístico tem pouco a ver com o de outros setores por estar sujeito muito mais as variáveis externas de ordem econômicas, políticas, sociais e até históricas, que outros setores". Neste sentido, Cooper (2001) afirma que as ações de marketing das organizações turísticas não podem ignorar as características básicas do turismo.

Considerando a definição de Lundberg (1990), o marketing turístico tem a função de identificar o que o destino turístico pode oferecer; quem dispõe de 
MIGUEL Giancarlos Francisco; SILVEIRA Ricardo Boeing da Vai pra onde? Análise do composto mercadológico de um destino turístico em Santa Catarina. Revista Brasileira de Pesquisa em Turismo. v. 2, n. 3, p. 54-89,

ISSN: $1982-6125$ nov. 2008.

tempo, dinheiro e interesse de se deslocar para esse local e ainda qual a melhor forma de comunicar e persuadir os interessados para tal processo.

Nesta definição, o autor enfatiza a coordenação de políticas de marketing em nível macro (negócios turísticos privados ou estatais e nacionais ou internacionais), sem se esquecer dos objetivos básicos de marketing, que visam à satisfação dos clientes e retorno para as empresas. Ao chegar num destino turístico, o turista necessita de uma série serviços que irão fazer parte da atividade turística como transporte, hospedagem, alimentação e entretenimento, observa Andrade (2002). O autor também ressalta que o turismo estimula o crescimento destes serviços que são prestados em sua maioria por empresas privadas, ao passo que aos organismos estatais (públicos) cabe a responsabilidade de elaboração e comercialização da oferta de um destino turístico e o desenvolvimento de facilidades turísticas, além de apoiar a promoção em nível institucional.

Diante do exposto, fica explícito que entidades públicas e privadas participam cada qual com a sua responsabilidade de ações que visam incrementar o processo de promoção e venda da oferta turística. Estas ações, realizadas de forma integrada e coordenada, farão parte de um planejamento turístico que será responsável pelo sucesso e o alcance dos objetivos traçados pelas empresas do setor (públicas e privadas) no mercado turístico que, apesar de um crescimento significativo, está cada vez mais concorrido.

Na visão de Beni (2001), quando se estuda um mercado, três questões merecem um cuidado especial: o que produzir; como produzir e a quem produzir. Para o autor, esses aspectos obedecem aos princípios de eficiência que prima em produzir com qualidade, a quantidade certa (eficiência atributiva), ao menor custo (eficiência produtiva) e aos consumidores certos com o melhor custo benefício (eficiência distributiva).

O conceito de mercado turístico adotado por Mota (2001) consiste em um conjunto de pessoas que compartilham de uma necessidade ou desejo, dispostos a realizar transações de troca que satisfaçam a sua necessidade. Castelli (1984), Lage e Milone (2000), numa outra ótica, destacam a interação 
MIGUEL Giancarlos Francisco; SILVEIRA Ricardo Boeing da Vai pra onde? Análise do composto mercadológico de um destino turístico em Santa Catarina. Revista Brasileira de Pesquisa em Turismo. v. 2, n. 3, p. 54-89,

da demanda e da oferta de produtos relacionados à execução e operacionalização das atividades que envolvem bens e serviços de viagens e afins.

O turismo é um fato econômico e social e as relações de troca de dinheiro por mercadorias e serviços turísticos formam o mercado turístico (CASTELLI, 1984). Em uma visão econômica, Balanzá (2003) trata o mercado turístico como parte da economia que estuda e analisa a realidade econômica do turismo com base nas relações entre oferta e demanda e o consumo dos produtos e serviços existentes neste mercado.

Para Lage e Milone (1999), o mercado turístico pode ser dividido em direto e indireto, de acordo com a natureza dos bens e serviços. No primeiro grupo, estão os produtos utilizados exclusivamente pelos turistas e, no outro, os produtos que são utilizados por diversos consumidores, incluindo a comunidade local.

De acordo com Beni (2001), para um produto turístico sobreviver em um mercado cada vez mais concorrido, deverá ser competitivo e isso dependerá de investimentos contínuos em inovação e melhoria da qualidade da oferta turística. Tabares (1991 apud Mota, 2001) contribui dizendo que a consolidação de um mercado não está simplesmente em sustentar as correntes turísticas atuais, mas também em incrementar o mercado com sólidas políticas mercadológicas.

Faz-se necessário ressaltar a presença de um personagem indispensável para a existência deste mercado, o produto turístico, que possui características próprias que o diferencia dos demais produtos.

O produto turístico surgiu com o aparecimento da sociedade de consumo, que teve como marco a produção massiva de bens e serviços. Este produto vem ao longo dos tempos se inserindo cada vez mais no contexto das necessidades básicas dos consumidores que vivem nos grandes centros urbanos, convivendo diariamente com a poluição e o estresse. Na percepção do turista, o produto turístico representa a soma da experiência vivida desde o 
MIGUEL Giancarlos Francisco; SILVEIRA Ricardo Boeing da Vai pra onde? Análise do composto mercadológico de um destino turístico em Santa Catarina. Revista Brasileira de Pesquisa em Turismo. v. 2, n. 3, p. 54-89, nov. 2008.

momento da saída até o seu retorno à sua residência permanente (RUSCHMANN, 1999; MIDDLETON, 2002).

Vaz (1999) explica que existem inúmeras definições para o produto turístico e a maioria delas descreve este produto como um conjunto de atrações procuradas pelos consumidores ou um complexo de serviços colocados à disposição pelas empresas do ramo.

Resumidamente Casteli (1986) define produto turístico como um conjunto de bens e serviços. Bissoli (1999) acrescenta que estes bens e serviços que um destino turístico oferece são diferenciados turisticamente e classificam-se em naturais e culturais, este último quando há a interferência do homem. Nesta ótica, Mota (2001) amplia as definições, afirmando que os produtos turísticos devem proporcionar ao homem satisfação de exigências fisiológicas, espirituais, culturais e morais, podendo ser materiais, imateriais, livres ou apropriáveis.

Para Tabares (1991 apud Mota, 2001), dentro das atividades turísticas "o que se vende são satisfações que se esperam obter pelo consumo de um produto". O autor ainda ressalta que o produto turístico é constituído de atrativos (ambientes natural, artificial e humano), facilidades (alojamento, alimentação, transporte, pessoal capacitado, etc.) e acessibilidade (vias de acesso terrestre, aéreo e marítimo). Middleton (2002) inclui na definição de Tabares mais dois componentes referentes ao produto turístico: imagem do destino e preço para o consumidor.

Segundo Ignarra (1999), o produto turístico engloba os elementos que formam a oferta turística, divididos em atrativos e serviços turísticos, serviços públicos e infra-estrutura básica. Para Lemos (2005), esses elementos estão ligados à atividade turística de maneira direta ou indireta e passam a ter valor turístico somente quando agrupados. Marchín (1993) e Ruschmann (1999) destacam que estes bens e serviços são interdependentes e extremamente complexos e, devido às suas singularidades, diferenciam-se dos demais produtos e serviços. 
MIGUEL Giancarlos Francisco; SILVEIRA Ricardo Boeing da Vai pra onde? Análise do composto mercadológico de um destino turístico em Santa Catarina. Revista Brasileira de Pesquisa em Turismo. v. 2, n. 3, p. 54-89, nov. 2008

De uma maneira mais específica, Boullón (1997), Ruschmann (1999) e Vaz (1999) descrevem o produto turístico como um conjunto de benefícios oferecidos por diversas organizações que inclui todas as atrações que um turista deseja quando decide viajar a uma determinada localidade.

Na interpretação de Lage e Milone (2000), o principal objetivo do produto turístico é atender aos desejos e às necessidades da demanda de viajantes, que aumenta numa proporção maior que a dos recursos econômicos existentes. Com a mesma concepção, Balanzá e Nadal (2003) determinam que os bens, serviços e infra-estruturas que compõem o produto turístico devem, além de satisfazer às motivações e às expectativas, oferecer vantagens e estarem disponíveis para o consumo dos turistas. Os autores ainda enfocam que este produto é composto de duas partes inseparáveis: a parte tangível (o produto em si) e a parte intangível (percepção e expectativas dos consumidores em relação aos produtos).

O produto turístico possui diferenças significativas em relação aos produtos físicos, principalmente no que diz respeito à natureza dos serviços, por isso é importantíssimo conhecer as suas características antes de qualquer estudo. Sobre as particularidades do produto turístico, Boullón (1997) chama a atenção para o fato destes não poderem ser estocados, seu consumo ser realizado no local de produção e ainda a influência que os preços sofrem da relação oferta-demanda. Este último fato é compartilhado e explicado por Lemos (2005) quando afirma que, por não ser de primeira necessidade, o mercado turístico é o primeiro a ser prejudicado em períodos de recessão. Estes mesmos autores divergem quando o assunto é a imaterialidade do produto turístico. Boullón (1997) destaca que o turista consome na realidade bens materiais (assento em um avião, colchão em um quarto de hotel, etc.), ao passo que Lemos (2000) ressalta que o estímulo no deslocamento de um visitante se dá por questões materiais e imateriais, interferindo nesse processo aspectos como atendimento nos equipamentos turísticos.

Para que o marketing possa desenvolver ações que visem à satisfação dos consumidores e gerem ao mesmo tempo retorno financeiro para a 
MIGUEL Giancarlos Francisco; SILVEIRA Ricardo Boeing da Vai pra onde? Análise do composto mercadológico de um destino turístico em Santa Catarina. Revista Brasileira de Pesquisa em Turismo. v. 2, n. 3, p. 54-89, nov. 2008.

empresa, é necessário o estudo detalhado de alguns fatores existentes em um negócio, responsáveis pelo sucesso ou fracasso de uma empresa.

Balanzá e Nadal (2003) descrevem que no desenvolvimento do processo de marketing distinguem-se várias etapas (pesquisa de mercado, criação do produto, fixação de preço, distribuição comercial e medição dos resultados) e em cada uma delas existirá um grande número de variáveis que deve ser considerado. Algumas, externas à empresa, não poderão ser controladas, enquanto outras se pode e se deve agir visando alcançar os objetivos organizacionais. Ao conjunto desses fatores internos da empresa dá-se o nome de mix de marketing.

De acordo com Churchill e Peter (2000) e Sandhusen (2003), entende-se por composto de marketing a combinação das ferramentas à disposição das organizações que possibilitam satisfazer a seus objetivos e dos clientes. De acordo com Mota (2001), composto de marketing ou marketing mix é o conjunto de quatro fatores fundamentais no processo de marketing e é conhecido como a teoria dos 4 Ps: produto, preço, promoção e praça (product, price, promotion, place). Balanzá e Nadal (2003) alertam para o fato de o composto de marketing não ser considerado apenas como uma mistura e sim uma combinação bem estruturada destas variáveis.

$\mathrm{Na}$ visão de Middleton (2002) o conceito de mix de marketing pode ser entendido como um conjunto de alavancas ou controles que podem ser operados pela empresa, a fim de atingir uma determinada meta. O autor ilustra esse pensamento comparando esses controles com os de um automóvel (acelerador, freio, câmbio e volante). Como é de conhecimento de todos, o movimento dos controles deve ser sincronizado de acordo com as condições da estrada em constantes mudanças e com as ações dos outros. O progresso efetivo requer uma manipulação contínua dos quatro controles básicos. De uma maneira mais simples, pode-se afirmar que estes fatores são as peças fundamentais do marketing, são como pilares que sustentam todas as ações que o marketing desempenha nas atividades das organizações. 
MIGUEL Giancarlos Francisco; SILVEIRA Ricardo Boeing da Vai pra onde? Análise do composto mercadológico de um destino turístico em Santa Catarina. Revista Brasileira de Pesquisa em Turismo. v. 2, n. 3, p. 54-89, nov. 2008.

Observando o pensamento de Kotler (2000), Kotabe e Helsen (2000); Bernardino et al. (2004), percebe-se que o preço é a única variável do composto de marketing que gera receita, influenciando diretamente na rentabilidade de uma organização. Outra característica relevante deste elemento é sua flexibilidade, podendo ser alterado com grande rapidez (KOTABE; HELSEN, 2000).

No contexto turístico, Middleton (2002) relata que qualquer visita a um destino tem um preço, que é proveniente do custo da viagem, acomodação e participação em uma gama selecionada de instalações e serviços. Para o autor, o preço sofre variações de acordo com a estação, opções de atividades, distâncias percorridas, meio de transporte utilizado e escolha de instalações e serviços.

Goeldner, Ritchie e McIntosh (2002) alertam para a importância da precificação dos produtos e serviços no mercado turístico, pois esta variável poderá afetar os outros elementos do composto de marketing, além de determinar como os consumidores irão perceber a oferta turística de um determinado destino. Lage e Milone (2000) destacam que nos dias de hoje, a noção de preço deixou de ser somente uma forma de gerar lucro, passando a ter a função também de atrair e conquistar novos clientes para o mercado turístico que associa o preço à imagem da natureza, qualidade, satisfação e outros atributos do produto na compra.

Adotando a visão de Ruschmann (1999), percebe-se que no turismo a política de preços pode estar voltada para três focos diferentes: oferta, demanda e concorrência e sua aplicação depende de fatores como estação do ano, dias da semana e até a categoria dos clientes para serem oferecidos de maneira eficaz. Vaz (1999) elucida que cada fornecedor de serviços turísticos possui sua própria política de preços e dentro deste cenário o setor público tem a responsabilidade de entrosar o trade turístico, no sentido de viabilizar produtos competitivos no mercado.

Ruschmann (1999) relata que os métodos de venda dos produtos turísticos não se relacionam com as formas de vendas dos produtos 
MIGUEL Giancarlos Francisco; SILVEIRA Ricardo Boeing da Vai pra onde? Análise do composto mercadológico de um destino turístico em Santa Catarina. Revista Brasileira de Pesquisa em Turismo. v. 2, n. 3, p. 54-89,

industrializados e de comércio. No caso dos produtos turísticos, deve-se levar o consumidor até o local da atração, onde os serviços são prestados.

De acordo com Castelli (1984), no turismo a distribuição da oferta pode ser feita de três maneiras: a empresa efetua a distribuição diretamente aos consumidores; opta por intermediários ou executa as duas formas simultaneamente. Esses canais são formados por estruturas organizacionais através das quais um produtor turístico descreve, vende ou confirma as operações para os compradores (GOELDNER; RITCHIE; MCINTOSH, 2002).

Para Middleton (2002), a variável praça (que compreende aspectos como local, distribuição e acesso) não se restringe apenas à localização de uma atração ou equipamento turístico, engloba também todos os pontos-de-venda que dão aos clientes potenciais acesso aos produtos turísticos. Vaz (1999) destaca a importância de um estudo adequado que direcione a distribuição dos produtos turísticos em mercados emissores com alta concentração de clientes potenciais.

Após a concepção de um produto e a definição de aspectos relacionados a preço e a distribuição, a empresa utilizará a comunicação para informar aos segmentos (finais e intermediários) a existência deste produto, não podendo, pois, ser esta ação realizada de forma isolada, como muitas vezes acontece (RUSCHMANN, 1999; VAZ, 1999). Esta etapa do composto de marketing é importantíssima para a consolidação do produto turístico e, segundo Vaz (1999), exige uma seleção estratégica das mídias, veículos de comunicação e das mensagens que serão utilizadas neste processo.

No entendimento de Lage e Milone (2000), a promoção é a atividade de comunicação dirigida a um determinado público, normalmente associada a vendas, realizada com intensa atuação de pessoas ou com auxílio de determinadas ferramentas. Os autores chamam atenção para a visão simplificada que se tem do conceito de comunicação. Para eles, todas as atividades da empresa devem ser consideradas como formas de se comunicar com o mercado. Assim, não se deve imaginar que somente os materiais promocionais e as peças de propaganda são percebidos pelos consumidores: o 
MIGUEL Giancarlos Francisco; SILVEIRA Ricardo Boeing da Vai pra onde? Análise do composto mercadológico de um destino turístico em Santa Catarina. Revista Brasileira de Pesquisa em Turismo. v. 2, n. 3, p. 54-89,

ISSN: $1982-6125$ nov. 2008.

atendimento ao telefone, o conteúdo de uma carta ou e-mail, o tratamento dos funcionários aos clientes, a existência ou não de estacionamento e o relacionamento da empresa com a comunidade, concorrência e fornecedores, todos estes elementos devem ser encarados como formas de comunicação com seu público-alvo.

No turismo, a atividade de divulgação (comunicar a existência de um destino) é executada por órgãos governamentais (esferas municipais, estaduais e até federais) e por empresas privadas (como hotéis, agências de viagem, etc.) que possuem diversos objetivos, de formas e amplitudes diferentes. Para Ruschmann (1999), o importante é que estas ações sejam realizadas de forma sistemática e que os objetivos comerciais estejam associados à satisfação das necessidades e desejos dos consumidores.

\section{METODOLOGIA}

Para alcançar os resultados estabelecidos neste trabalho, utilizaram-se pesquisas do tipo exploratória e descritiva. A pesquisa exploratória foi utilizada na busca de informações referente às quatro variáveis do composto de marketing, através de entrevistas com representantes dos setores público e privado. Segundo Aaker (2001) e McDaniel (2003), a pesquisa exploratória é de pequena escala e usada para definir a natureza de um problema. Segundo os autores, seus métodos são flexíveis, não estruturados e qualitativos, para que o estudo comece sem pré-concepções acerca do que será encontrado, além de fornecer ao pesquisador maior conhecimento sobre determinado assunto. Já a pesquisa descritiva, segundo Gil (1999), Mattar (1999) e Aaker (2001), é um dos tipos mais utilizados em marketing, pois através dela é possível identificar as relações e a natureza das variáveis envolvidas em um processo. 
MIGUEL Giancarlos Francisco; SILVEIRA Ricardo Boeing da Vai pra onde? Análise do composto mercadológico de um destino turístico em Santa Catarina. Revista Brasileira de Pesquisa em Turismo. v. 2, n. 3, p. 54-89, nov. 2008.

Neste estudo, a pesquisa descritiva foi utilizada na obtenção de dados secundários em fontes como meio eletrônico, revistas e materiais promocionais pertinentes à cidade e seu entorno, contextualizando essa região no mercado turístico e descrevendo as principais características destes destinos.

A coleta de informações realizada neste trabalho foi através do método qualitativo, que na percepção de Aaker (2001), tem o propósito de descobrir o que o consumidor tem exatamente em mente. $O$ autor ainda afirma que este método fornece perspectivas de suas idéias e ajuda o pesquisador a compreender as preocupações dos consumidores.

A pesquisa foi realizada com a Secretária de Turismo e com o Presidente da Associação Empresarial da cidade analisada por meio de uma entrevista pessoal com um roteiro semi-estruturado, contendo questões abertas e não disfarçadas, com o intuito de cobrir uma lista específica de assuntos. Os entrevistados puderam responder às questões livremente, com suas próprias palavras, fornecendo respostas mais espontâneas e valiosas. Aaker (2001) argumenta que questões altamente estruturadas e fechadas deixam pouca margem de escolha, enquanto que as questões abertas e pouco estruturadas oferecem uma ampla gama de alternativas. O autor ainda ressalta que as entrevistas semi-estruturadas são extremamente demandantes e dependem muito da habilidade do entrevistador, ficando a seu critério os termos exatos e o tempo alocado para cada uma das questões.

Para atingir o objetivo pretendido neste trabalho, buscou-se a percepção do Poder Público e da Iniciativa Privada em relação às variáveis que compõem o composto mercadológico deste destino. As quatro variáveis (produto, preço, praça e promoção) foram subdivididas em categorias pelo entrevistador. No produto, buscou verificar, através de Ignarra (1999), os atrativos, os equipamentos e serviços turísticos, além da infra-estrutura básica necessária em um destino. Fundamentadas em Middleton (2002) foram investigadas as instalações turísticas, imagem e ciclo de vida do produto turístico. O preço foi dividido em custo do produto turístico para o turista, fundamentado em Middleton (2002) e preços regulares e promocionais, baseados em Lage e 
MIGUEL Giancarlos Francisco; SILVEIRA Ricardo Boeing da Vai pra onde? Análise do composto mercadológico de um destino turístico em Santa Catarina. Revista Brasileira de Pesquisa em Turismo. v. 2, n. 3, p. 54-89,

ISSN: 1982-6125 nov. 2008.

Milone (2000). Na variável praça, Casteli (1986) descreve os canais de distribuição e os mercados emissores são conceituados por Wahab (1991). Na promoção as categorias foram fundamentadas em Vaz (1999); argumentos nas promoções, Goeldner, Ritchie e McIntosh (2002), principais objetivos, Acerenza (1991) e Middleton (2002) as ferramentas utilizadas e Ruschmann (1999) integração dos 4 Ps de marketing e as parcerias nas ações promocionais, como pode ser visto abaixo:

- Produto: esta variável no setor turístico é definida por Ignarra (1999) como a somatória dos atrativos e serviços turísticos, serviços públicos e infra-estrutura básica necessários para o bom funcionamento $e$, conseqüentemente, o consumo por parte dos turistas e visitantes, Lemos (2005) contribui nesta questão, complementando que estes elementos só possuem valor quando agrupados. Diante do exposto, foram colhidas informações dos atrativos turísticos da cidade, dos serviços que compõem estes produtos, dos serviços realizados pelo Poder Público Municipal e como se encontra a infra-estrutura turística deste destino.

- Preço: é o elemento mais flexível do mix de marketing e teve sua análise fundamentada num pensamento de Bernardino (2004), no qual o preço exerce influência direta na imagem que os consumidores têm em relação a um produto. Baseando-se neste pensamento, verificou-se como este destino utiliza o elemento preço em suas ações mercadológicas frente ao seu mercado consumidor.

- Praça: o aspecto de distribuição no turismo foi investigado levando em consideração a visão de Ruschmann (1999), que distingue os métodos de venda de produtos do setor turísticos com os demais setores pelo fato do deslocamento ser realizado pelo consumidor até o local onde os serviços são prestados. Foram obtidas informações de como são atraídos os turistas para a cidade e de que maneira este destino se torna acessível a seus clientes.

- Promoção: na visão de Keegan e Green (2000), a promoção de um destino turístico tem, na maioria das vezes, a função de aumentar ou equilibrar a sua demanda. Para Ruschmann (1999), o processo de comunicação deve estar 
MIGUEL Giancarlos Francisco; SILVEIRA Ricardo Boeing da Vai pra onde? Análise do composto mercadológico de um destino turístico em Santa Catarina. Revista Brasileira de Pesquisa em Turismo. v. 2, n. 3, p. 54-89,

ISSN: $1982-6125$ nov. 2008.

interligado com as outras variáveis do composto de marketing. Apoiando-se nestas definições, foram verificadas as principais ações promocionais que 0 Poder Público e a Iniciativa Privada realizam para equilibrar a demanda deste destino turístico durante o ano inteiro e se estas ações estão em consonância com as demais variáveis do composto marketing da cidade.

Participaram da pesquisa o Poder Público Municipal, representado pela Secretária de Turismo e Desenvolvimento Econômico e a Iniciativa Privada, representada pela Associação Comercial e Industrial, na pessoa do seu presidente. O roteiro utilizado foi o mesmo para os dois entrevistados, com pequenas modificações visando adaptar 'o sujeito' nas questões. $O$ fato das entrevistas serem realizadas com o mesmo roteiro obedece à pretensão de se obter as respostas sobre os mesmos aspectos do composto mercadológico.

A escolha da amostra foi intencional por julgamento, em que os critérios de seleção são baseados na experiência pessoal de que os elementos sejam representativos da população em estudo (MCDANIEL, 2003). De acordo com Aaker (2001), a amostragem intencional está associada a uma variedade de tendências, algumas óbvias, outras nem tanto. Para o autor, em determinadas situações (quando a amostra probabilística é inviável em termos de custo ou o tamanho desta for pequeno) é aconselhável a utilização de amostras intencionais.

\section{RESULTADOS}

Neste estudo, foram utilizados dados de fonte primária e secundária. As informações de base primária foram obtidas através de entrevistas e analisadas qualitativamente, empregando-se diversos conceitos presentes na fundamentação teórica deste trabalho. Já as informações de fontes secundárias foram obtidas através de pesquisas em meios eletrônicos (internet) e impressos (revistas, folders, informativos). Depois de analisados, os dados foram apresentados em um texto narrativo e informal, com citações 
MIGUEL Giancarlos Francisco; SILVEIRA Ricardo Boeing da Vai pra onde? Análise do composto mercadológico de um destino turístico em Santa Catarina. Revista Brasileira de Pesquisa em Turismo. v. 2, n. 3, p. 54-89, nov. 2008.

dos entrevistados e dos autores que fundamentaram as categorias analisadas na pesquisa.

As quatro variáveis do composto de marketing foram divididas em categorias pelo entrevistador, com o intuito de facilitar o trabalho de coleta e análise dos dados. Vale ressaltar que esta divisão se deu devidamente fundamentada em autores como Ignarra (1999), Middleton (2002), Ruschmann (1999), Goeldner, Ritchie e McIntosh (2002), Lage e Milone (2000), Vaz (1999), Boone e Kurtz (1998), Castelli (1984) e Wahab (1991), todos especialistas em marketing ou em turismo, visando dar credibilidade ao trabalho realizado.

Esta variável foi subdividida em cinco categorias: atrativos, instalações e serviços turísticos, infra-estrutura, imagem e ciclo de vida do produto. Tal divisão foi fundamentada em Ignarra (1999), que descreve o produto turístico como a somatória dos atrativos e serviços turísticos, serviços públicos e a infra-estrutura básica. Já as categorias fundamentadas em Middleton (2002) foram as instalações turísticas, imagem e ciclo de vida do produto turístico.

Na visão de ambos os entrevistados (Secretária de Turismo e Presidente da Associação Empresarial) a principal atração turística da cidade está ligada ao turismo de lazer de praia, mais conhecido como turismo de 'sol e mar'. De acordo com Ruschmann (1999) e Lage e Milone (2000), os atrativos turísticos são os elementos que influenciam os turistas a escolher um destino em vez de outro e referem-se ao ambiente natural, cultural e também a acontecimentos no destino turístico. Percebe-se com esta definição que o principal atrativo da cidade é natural e, segundo Goeldner, Ritchie e McIntosh (2002) estes atrativos são a 'mola propulsora' que leva as pessoas a viajar.

Na opinião da Secretária de Turismo, este produto está em transição, mudando o foco para um turismo voltado para a natureza com ênfase nas áreas ecológicas, de contemplação e esportes de natureza. Ela ainda alertou para a falta de consciência da comunidade local (incluído moradores e empresários) a respeito dessa necessária transição, "não podemos oferecer uma única opção ao turista que escolhe a nossa cidade para descansar, [...] 
MIGUEL Giancarlos Francisco; SILVEIRA Ricardo Boeing da Vai pra onde? Análise do composto mercadológico de um destino turístico em Santa Catarina. Revista Brasileira de Pesquisa em Turismo. v. 2, n. 3, p. 54-89, nov. 2008.

temos que aproveitar todo o nosso potencial e passar a ter um amplo leque de opções para estes turistas".

Nessa mesma concepção, o Presidente da Associação Empresarial afirma que a cidade não está suficientemente estruturada em relação aos seus atrativos para atender a seus visitantes. No que se refere aos aspectos naturais, o destino é dotado de uma boa estrutura fornecida pela natureza. Mas em relação às ações do homem ainda falta muita coisa. "Esquecemos de pensar no conjunto de atrativos que poderiam compor o cenário e agregar valor e qualidade a este turismo". Prova disto é que "quando chove uma semana, principalmente no verão é um Deus nos acuda, não existe o que poderíamos chamar de plano B. [...] precisamos desenvolver outros aspectos que não sejam os naturais para satisfazer as expectativas dos turistas quando o sol e o mar não atingirem esses objetivos".

Segundo Lage e Milone (2000) nesta categoria estão inseridos os meios de hospedagem, alimentação, entretenimento, informações e outros serviços voltados para o atendimento aos turistas. Middleton (2002) complementa afirmando que os elementos que compõem essa categoria devem possibilitar aos visitantes ficar, aproveitar ou participar das atrações turísticas.

Para o representante da Associação Empresarial de Bombinhas - AEMB, as instalações e os serviços turísticos atendem em parte à demanda atual de turistas da cidade. Em setores como o de acomodação e alimentação, algumas empresas se sobressaem oferecendo equipamentos e serviços de qualidade, apesar de ainda não existir restaurantes preocupados com produtos e serviços diferenciados. Na sua visão, "faltam bares e restaurantes não apenas sofisticados, mas que tenham pontos marcantes, que encantem seus clientes com gestos marcantes e pela agradabilidade". Outra ausência citada pelo entrevistado é em relação ao transporte na cidade. O existente é precário, forçando os turistas a utilizarem seus veículos para chegarem aos atrativos turísticos, ocasionando engarrafamentos e estresse, fatores esses que os turistas tentam fugir quando vêm para este destino. 
MIGUEL Giancarlos Francisco; SILVEIRA Ricardo Boeing da Vai pra onde? Análise do composto mercadológico de um destino turístico em Santa Catarina. Revista Brasileira de Pesquisa em Turismo. v. 2, n. 3, p. 54-89, nov. 2008.

Já a Secretária de Turismo da cidade defende o fato de a maioria dos equipamentos e serviços turísticos estar muito abaixo das expectativas do turista. Salvo algumas exceções, os empreendimentos não preparam sua mãode-obra, muitas empresas sequer criam vínculos empregatícios com seus colaboradores, em virtude do curto período de alta demanda existente na cidade. Segundo ela, "a cidade fecha depois da temporada de verão" e com isso o destino turístico como um todo fica comprometido. Para ilustrar esta situação, foi relatada pela Secretária uma parceria do Poder Público com o Serviço Brasileiro de Apoio às Micros e Pequenas Empresas (SEBRAE) e com o Serviço Nacional de Aprendizagem Comercial (SENAC) visando aperfeiçoar a mão-de-obra principalmente dos equipamentos turísticos do destino, mas por falta de participantes os cursos acabaram não sendo realizados. Este aspecto é no mínimo preocupante, pois considerando a idéia de Vaz (1999), a atuação da mão-de-obra no mercado turístico é decisiva em termos de atendimento e qualidade do produto. Ainda para a Secretária de Turismo o Poder Público como um todo ainda não tem consciência de sua responsabilidade em relação aos serviços que devem ser prestados. Tudo é feito em cima da hora e os motivos que prevalecem são a falta de planejamento e de recursos disponíveis para estas ações.

Acerca dos serviços turísticos ainda foi relatado pela $A E M B$ que falta muito a ser feito e destaca o papel do Poder Público nessa questão, não como órgão responsável pela execução das ações, mas como fomentador, desempenhando um papel de liderança e buscando conduzir todos os segmentos rumo ao mesmo pensamento. Segundo ele, "o Poder Público se esforça, faz de maneira razoável o que a lei lhe obriga e por muitas vezes se omite ao que lhe é facultativo e com isso o turismo da cidade deixa a desejar em alguns aspectos".

As instalações básicas e de serviços descritos como infra-estrutura são de importância fundamental para o sucesso do turismo. Sistemas de águas e esgoto, instalações elétricas, sistemas de comunicação, vias de acesso e o 
MIGUEL Giancarlos Francisco; SILVEIRA Ricardo Boeing da Vai pra onde? Análise do composto mercadológico de um destino turístico em Santa Catarina. Revista Brasileira de Pesquisa em Turismo. v. 2, n. 3, p. 54-89,

ISSN: 1982-6125 nov. 2008.

recolhimento de lixo devem ser planejados com perspectiva de longo prazo, prevendo necessárias ampliações (GOELDNER; RITCHIE; MCINTOSH, 2002).

De acordo com o Presidente da AEMB, a infra-estrutura do destino turístico ainda é muito precária, faltando investimentos em todos os setores. Segundo ele, é imprescindível implantar o sistema de saneamento básico; melhorar o abastecimento de água, principalmente, nos períodos de demanda excessiva na cidade; dar condições de tráfego aos acessos que ligam os principais pontos turísticos; além de calçadas que permitam acessibilidade de todos e lixeiras espalhadas por toda a cidade. Opinião compartilhada pela Secretária de Turismo, que vê uma excessiva preocupação com a infraestrutura geral (escolas, postos de saúde, campos de futebol) e uma 'despreocupação' com a infra-estrutura específica que deve atender diretamente ao turista.

Na ótica de Vaz (1999), a imagem de uma destinação turística é um conjunto de idéias correntes sobre a localidade. Complementando tal afirmação, Middleton (2002) afirma que a imagem do destino não é necessariamente baseada em experiências e fatos, mas é sempre um motivador poderoso em turismo.

Quando questionados sobre a imagem do destino turístico, ambos os entrevistados declaram que esta ainda permanece com um conceito elevado por seus moradores, 'vendedores' e visitantes. Segundo eles, as pessoas apontam defeitos, mas ainda preferem os problemas encontrados no destino aos encontrados na cidade de origem. Na percepção da AEMB, fica evidente que se fossem realizadas melhorias aumentaria ainda mais o valor agregado dos negócios estabelecidos na cidade.

Para Goeldner, Ritchie e McIntosh (2002), as constantes mudanças no mercado afetam os hábitos dos consumidores e fazem com que todos os produtos passem por várias fases chamadas de ciclos de vida.

Foi exposto pela Secretária de Turismo que o principal produto oferecido pelo destino turístico aos seus consumidores, o turismo de 'sol e mar', está em franco declínio. O turista, quando decide por um destino, espera encontrar 
MIGUEL Giancarlos Francisco; SILVEIRA Ricardo Boeing da Vai pra onde? Análise do composto mercadológico de um destino turístico em Santa Catarina. Revista Brasileira de Pesquisa em Turismo. v. 2, n. 3, p. 54-89, nov. 2008.

uma série de vantagens e suprir suas expectativas. A saída para esta situação, no entender deste órgão, é ampliar a oferta de atrações ao turista. "[...] temos uma história riquíssima, além da culinária típica e tradições seculares deixadas pelos antepassados que bem estruturadas e utilizadas de forma correta podem se transformar num ótimo produto turístico".

Já na visão do Presidente da Associação Empresarial, a Cidade como destino turístico se encontra no estágio de maturação no processo de ciclo de vida. Ele argumenta que esse produto turístico pode crescer muito e, para isso, considera aspectos relevantes: a cidade ainda preserva ares de localidade pequena, possui um nível de segurança razoável e as suas praias ainda são muito recomendadas. "É necessário apenas estabelecer prioridades, focar alvos e colocá-los em prática".

Para o elemento preço, as categorias elaboradas foram: custo para o turista e preço regular e promocional. $O$ custo do produto turístico para o turista foi fundamentado na visão de Middleton (2002), na qual o preço é originário do custo da viagem, acomodação e participação em uma gama selecionada de instalações e serviços, enquanto que a percepção dos preços regulares e promocionais, utilizados para equilibrar a demanda turística, foi baseada em Lage e Milone (2000).

$\mathrm{Na}$ ótica da $A E M B$, os preços praticados na cidade parecem adequados, embora algumas empresas ainda definam seus preços de acordo com a demanda, alterando valores à medida que o consumo aumenta ou diminui. Para o entrevistado, em geral, não há fortes reclamações quanto aos preços.

Esta opinião não é a mesma apontada pela Secretaria de Turismo que, no seu entendimento, os preços são altos demais, considerando o que é ofertado. Ainda existem empresas que preferem explorar os turistas em períodos que a demanda supera a oferta e, à medida que a procura diminui, os preços vão caindo na mesma proporção da sua qualidade, influenciando na percepção de valor que os turistas têm em relação ao destino turístico.

Acerca do exposto, Vaz (1999) aponta para o fato de cada fornecedor de serviços turísticos possuir uma política própria de preços e o setor público tem 
MIGUEL Giancarlos Francisco; SILVEIRA Ricardo Boeing da Vai pra onde? Análise do composto mercadológico de um destino turístico em Santa Catarina. Revista Brasileira de Pesquisa em Turismo. v. 2, n. 3, p. 54-89, nov. 2008.

a responsabilidade de entrosar o trade turístico no sentido de viabilizar produtos competitivos no mercado. Para a entrevistada, isto compromete a imagem que os turistas passam a ter da cidade, enxergando-a como um destino que explora seus visitantes. Este pensamento é compartilhado por Goeldner, Ritchie e McIntosh (2002), o qual defende que o preço pode determinar a percepção dos consumidores em relação a um produto e ainda afetar as outras variáveis do composto de marketing. Este aspecto de adoção de determinadas políticas de preço é entendido por Lage e Milone (2000) de maneira natural, quando visa adaptar a demanda em função da oferta turística, sendo comum em destinos que sofrem com a sazonalidade. Nos destinos turísticos, os períodos em que a demanda é maior (férias escolares, temporada de verão, etc.) os preços tendem a ser mais elevados e tendem a baixar à medida que a demanda comece a diminuir.

Na variável praça ou aspectos relacionados aos canais de distribuição foram eleitos de acordo com a teoria de Castelli (1984), onde a empresa efetua a distribuição diretamente aos consumidores, opta por intermediários ou executa as duas formas simultaneamente. Ainda neste elemento foram investigados os principais mercados emissores de turistas e visitantes, que segundo Wahab (1991), podem ser classificados em reais (indivíduos que realmente viajam para determinado local) e potenciais (número de pessoas que estão em condições de viajar).

A Secretaria de Turismo da cidade tem como principal canal de distribuição do seu produto a participação em eventos e feiras de turismo, com o intuito de efetuar contatos com operadores e agentes de viagens. Outro canal disponível é o website da cidade, apesar deste não estar estruturado para vender o destino de maneira eficiente.

Já a maioria das empresas que compõem o trade turístico efetua a distribuição de seus produtos de forma direta aos consumidores finais. Para isso, a principal ferramenta utilizada é a internet. Outra estratégia adotada por algumas empresas de hospedagem é visitar diretamente algumas operadoras e 
MIGUEL Giancarlos Francisco; SILVEIRA Ricardo Boeing da Vai pra onde? Análise do composto mercadológico de um destino turístico em Santa Catarina. Revista Brasileira de Pesquisa em Turismo. v. 2, n. 3, p. 54-89,

agentes de viagens, fazendo um contato direto, sem a correria de um evento especializado do setor.

Segundo Ruschmann (1999), no turismo a distribuição dos produtos turísticos pode ser feita diretamente ao consumidor final ou utilizando-se de intermediários (operadores turísticos, agentes de viagem, representantes de vendas, etc.). Vaz (1999) ressalta a necessidade de um estudo adequado que direcione a distribuição e a venda dos produtos turísticos nos centros emissores selecionados como pontos de concentração do público-alvo.

Quanto aos principais mercados emissores, foram apontados os estados do Paraná e do Rio Grande do Sul, no Brasil, e a Argentina como mercados reais. Já como mercados potenciais, foram citados o interior de Santa Catarina, o Estado de São Paulo, Mato Grosso do Sul, além do Uruguai, fora do país.

Na última variável do composto de marketing, as categorias utilizadas na pesquisa foram divididas fundamentadas nos pensamentos de Vaz (1999), examinando as principais informações utilizadas como argumentos nas promoções, Goeldner, Ritchie e McIntosh (2002) observando os objetivos, Acerenza (1991) e Middleton (2001) as ferramentas mais utilizadas e Ruschmann (1999) verificando a integração da promoção com os outros 'Ps' de marketing e as parcerias existentes entre o trade turístico e o Poder Público.

Na visão da Secretária de Turismo, o principal argumento utilizado no processo de comunicação do destino com seu público ainda são 'o sol e o mar'. Na sua concepção, estes argumentos estão perdendo força e a nova estratégia que deverá ser utilizada está focada em apelos emocionais e ligados a momentos de experiências e sensações únicas. No setor privado, cada empresa possui seus argumentos que variam de acordo com o segmento informado. Os mais utilizados pelos equipamentos de hospedagem, por exemplo, são aspectos como segurança, conforto e serviços de qualidade, além da própria estrutura física que na maioria dos casos pode influenciar a compra deste produto.

Quanto ao principal intuito do processo de comunicação, os entrevistados compartilham da idéia que, atualmente, a grande necessidade da cidade como 
MIGUEL Giancarlos Francisco; SILVEIRA Ricardo Boeing da Vai pra onde? Análise do composto mercadológico de um destino turístico em Santa Catarina. Revista Brasileira de Pesquisa em Turismo. v. 2, n. 3, p. 54-89,

destino turístico é equilibrar a demanda durante todos os meses do ano. Ampliar a permanência dos turistas e o período de alta temporada são pretensões ambiciosas, mas que podem ser alcançadas com muito trabalho e ações de médio e longo prazos. O Presidente da AEMB destacou que para a demanda turística aumentar e passar a visitar a cidade em outros períodos do ano, os equipamentos turísticos deverão estar esperando pelo turista para que este não retorne para o seu local de origem com a impressão de que a cidade só vive no verão. O objetivo promocional adotado pelo destino turístico é condizente com a teoria de Boone e Kurtz (1998) e Goeldner, Ritchie e McIntosh (2002), quando visa equilibrar o consumo aumentando a demanda em períodos de menos procura, e ainda diferenciando o atual produto, agregando ao turismo de praia atrações vinculadas a natureza.

As principais ferramentas utilizadas pela Secretaria de Turismo são os materiais gráficos como folders, folhetos, sacolas promocionais, vídeos institucionais e participação em eventos. Durante o ano de 2007, foram realizados inúmeros contatos com operadores e agentes de viagens e distribuídos milhares de materiais promocionais do destino. As participações nos eventos acontecem em parceria com a SANTUR, no caso de eventos internacionais, e com os municípios que fazem parte da Associação dos Municípios da Região da Foz do Rio Itajaí (AMFRI) em eventos nacionais.

Para a AEMB, a participação em eventos de turismo não traz resultados satisfatórios para o setor privado, "[...] ali não se faz negócios e nem se atinge o cliente, ele não vai lá para comprar o destino". Segundo o entrevistado, existem outros instrumentos mais acessíveis e muito mais eficazes, citando como exemplos publicações do gênero como o 'Guia 4 Rodas' e a 'Revista Viagem e Turismo', pois possuem uma grande influência junto às pessoas que planejam viajar.

De maneira geral, as empresas particulares utilizam as mesmas ferramentas citadas pelo Poder Público, acrescentando ainda que algumas do setor de acomodação utilizam o telemarketing (ativo ou passivo) e Relações Públicas, esta última ferramenta visando conseguir mídia nos principais 
MIGUEL Giancarlos Francisco; SILVEIRA Ricardo Boeing da Vai pra onde? Análise do composto mercadológico de um destino turístico em Santa Catarina. Revista Brasileira de Pesquisa em Turismo. v. 2, n. 3, p. 54-89, nov. 2008.

veículos de comunicação do setor. Goeldner, Ritchie e McIntosh (2002) afirma que promoção é um termo muito amplo que inclui propaganda, venda pessoal, relações públicas, publicidade e atividades de promoção de vendas, como brindes, feiras comerciais, etc. Acerca desta questão, o representante da AEMB relata que o setor privado ainda esta 'engatinhando' no que diz respeito à promoção turística, "[...] por muito tempo ficamos esperando que o Poder Público se movimentasse com 0 intuito de atrair clientes para negócios particulares". Na sua visão, isso não compete ao setor público, este precisa criar condições estruturais para receber bem os turistas e fazer com que a população fixa se sinta bem na cidade.

Quando questionados sobre a integração da variável promoção com os outros Ps do composto de marketing, ambos os pesquisados afirmaram que isso ainda não acontece freqüentemente com as empresas que atuam na cidade. De acordo com Ruschmann (1999), o sucesso de qualquer empresa está em administrar de maneira eficaz seu composto de marketing e isso requer integração entre as suas variáveis. No pensamento da Secretária de Turismo, o empresariado local possui uma visão imediatista, esperando que todos os resultados aconteçam sem planejamento e no menor espaço de tempo possível, segundo ela, "[...] não temos integração com as outras variáveis, pois alguns empresários preferem fazer turismo de três meses".

Opinião muito parecida possui a AEMB, declarando que é necessária uma mudança de mentalidade por parte dos setores público e privado. Segundo o presidente desta associação, existe um vácuo entre a variável promoção e as outras que compõem o mix de marketing. "[...] é preciso que os responsáveis pelo gerenciamento das empresas estejam sintonizados com seu público e se desprendam do foco único do faturamento e passem a se preocupar em fidelizar seus clientes criando relacionamentos duradouros e rentáveis".

A última categoria analisada na variável promoção foi a existência de parcerias entre os setores Público e Privado. Ruschmann (1999) relata que no turismo a promoção pode ser realizada tanto pelos órgãos governamentais (divulgando um destino) como por empresas privadas (hospedagem, 
MIGUEL Giancarlos Francisco; SILVEIRA Ricardo Boeing da Vai pra onde? Análise do composto mercadológico de um destino turístico em Santa Catarina. Revista Brasileira de Pesquisa em Turismo. v. 2, n. 3, p. 54-89,

ISSN: 1982-6125 nov. 2008.

alimentação, etc.), sendo fundamental que estas ações sejam executadas de maneira integrada atingindo todos os objetivos propostos. No entender da $A E M B$, esta relação de parcerias é pequena ou quase inexistente. Segundo seus relatos, para alguns empresários ser parceiro é misturar interesses ou se expor à concorrência e são extremamente imediatistas, pensam primeiro no que vai resultar para o próprio negócio. Sobre as parcerias com o Poder foi relatado que este órgão é parceiro nos momentos de apresentar contas e responsabilidades, esquecendo-se de sua função fomentadora. Na visão do entrevistado, isso é possível sem comprometer as receitas do município e seus créditos fiscais, basta agir como integrador nas ações de promoção do destino turístico.

A Secretaria de Turismo também descreve que ainda são insuficientes as parcerias entre as empresas do setor turístico e entre essas e o setor público. Ela é otimista quando afirma acreditar que este quadro tende a se modificar lentamente com o passar do tempo. "[...] já foi bem pior, não existia diálogo. Os empresários só se aproximavam do poder público para pedir alguma coisa e - poder público também procurava as empresas somente para realizar cobranças". Já houve evolução nesse sentido e como prova disto foi produzido em parceria com a iniciativa privada um vídeo institucional da cidade que está sendo distribuído em eventos ou enviado para operadores e agências de turismo.

\section{CONCLUSÕES}

Verificou-se que as praias são os principais atrativos dessa região que acabam "disputando" mercado com o mesmo produto turístico. Apesar disto, cada cidade apresenta outras características na sua oferta turística.

Para identificar a atual situação das variáveis do composto de marketing. Para isso, foi realizada uma entrevista com um roteiro semi-estruturado com os representantes dos setores público e privado da cidade, no intuito de observar as percepções de cada um referente a esses elementos. Foram 
MIGUEL Giancarlos Francisco; SILVEIRA Ricardo Boeing da Vai pra onde? Análise do composto mercadológico de um destino turístico em Santa Catarina. Revista Brasileira de Pesquisa em Turismo. v. 2, n. 3, p. 54-89, nov. 2008.

criadas categorias para cada variável do composto mercadológico. No produto, aspectos como atrações, instalações e serviços, infra-estrutura, imagem e ciclo de vida ganharam destaque. Os atrativos naturais são o grande "forte" da cidade, atraindo milhares de turistas à procura de belas praias e paisagens encantadoras. Mas ficou evidente a necessidade de se ampliar as opções de atrativos deste destino, com o intuito de solucionar problemas com a demanda de turistas na cidade quando o sol e o mar não estiverem disponíveis.

Outro aspecto que merece atenção e investimentos é toda parte de infraestrutura geral e específica da cidade. Verificou-se que o saneamento básico e os acessos a este destino são problemas que precisam de soluções urgentes, pois estão comprometendo a qualidade do produto no cenário turístico.

Quanto aos equipamentos e serviços oferecidos pelo trade e pelo Poder Público ao turista durante sua permanência na cidade, constatou-se que os setores de acomodação e alimentação são os mais desenvolvidos e que diversos serviços prestados precisam de melhor qualificação. Parte desses problemas vem do fato de muitas empresas trabalharem apenas durante os três meses da temporada de verão, não conseguindo continuidade $e$, conseqüentemente, qualidade nos produtos e serviços que ofertam aos seus consumidores.

Mesmo com todas as suas deficiências, a imagem deste destino turístico se configura de forma positiva na mente dos seus consumidores, pois ainda consegue satisfazer às expectativas e desejos de quem vive ou visita este lugar. Considerando este aspecto, a cidade como produto turístico encontra-se num bom momento do seu ciclo de vida e muito ainda poderá ser aproveitado. Mas como um produto de "sol e mar", este destino passa por um momento de declínio, necessitando passar por mudança, afim evitar a sua extinção no mercado turístico.

O preço foi a segunda variável observada na investigação e não houve consenso na opinião dos pesquisados. Do lado do trade, percebe-se uma compatibilidade com os valores cobrados e os produtos e serviços oferecidos, 
MIGUEL Giancarlos Francisco; SILVEIRA Ricardo Boeing da Vai pra onde? Análise do composto mercadológico de um destino turístico em Santa Catarina. Revista Brasileira de Pesquisa em Turismo. v. 2, n. 3, p. 54-89, nov. 2008.

enquanto que na visão do setor público os preços praticados pelas empresas estão além do que elas apresentam aos seus clientes.

A terceira variável observada foi a distribuição deste destino no mercado turístico, conhecida como "praça" dentro do composto de marketing. Verificouse que a venda deste destino é efetuada na sua grande maioria de forma direta pelas empresas que compõem o trade turístico, sem a participação de intermediários como os agentes e operadores de viagem.

Finalizando a análise do composto de marketing, foi analisada a promoção realizada ao seu público consumidor. O principal argumento utilizado nas ações promocionais ainda está relacionado ao turismo de praia e com a junção do sol e o mar presentes neste destino. As principais ferramentas utilizadas são participações em eventos do setor onde há a distribuição de material promocional do destino, além de anúncios e reportagens publicadas em mídias especializadas em turismo. Essas ações não são realizadas em parceria e a integração dessa variável com as demais do composto de marketing também não acontece, principalmente em virtude da falta de planejamento das empresas do setor público e privado do destino turístico.

Tomando como base as limitações encontradas neste trabalho, recomenda-se o desenvolvimento dos seguintes aspectos pertinentes ao tema em futuros estudos: investigar as variáveis que formam o composto de marketing (produto, preço, praça e promoção) do ponto de vista da comunidade local e dos turistas e visitantes durante a baixa e a alta temporada, pois neste trabalho apenas os setores público (secretaria de turismo) e privado (associação empresarial) da cidade participaram da entrevista, e não os seus turistas e moradores; analisar as principais ações promocionais realizadas pelos setores público e privado da cidade, verificando o retorno em termos de receita e número de visitantes.

\section{REFERÊNCIAS}


MIGUEL Giancarlos Francisco; SILVEIRA Ricardo Boeing da Vai pra onde? Análise do composto mercadológico de um destino turístico em Santa Catarina. Revista Brasileira de Pesquisa em Turismo. v. 2, n. 3, p. 54-89,

AAKER, Davida. Pesquisa de marketing. São Paulo: Atlas, 2001.

ACERENZA, Miguel Angel. Promoção turística: um enfoque metodológico. São Paulo: Pioneira, 1991.

ANDRADE, José Vicente de. Turismo: fundamentos e dimensões. 8. ed. São Paulo: Ática, 2002.

ARENDIT, Ednilson José. Introdução à economia do turismo. 2. ed. Campinas: Alínea, 2000.

BALANZÁ, Isabel Milio; NADAL, Mônica Cabo. Marketing e comercialização de produtos turísticos. São Paulo: Pioneira Thomson Learning, 2003.

BARBOSA, Ycarim Melgaço. Histórias das viagens e do turismo. São Paulo: Aleph, 2002.

BARRETO, Margarita. Manual de iniciação ao estudo do turismo. Campinas: Papirus, 1995.

Campinas: Papirus, 1996.

Planejamento e organização em turismo. 2. ed.

BARROS, P. M. Indicadores necessários à formulação de políticas públicas locais para o turismo sob a ótica dos stakeholders institucionais estratégicos. 2005 Tese (Doutorado em Engenharia da Produção) Universidade Federal de Santa Catarina, Florianópolis, 2005.

BENI, M. C. Análise estrutural do turismo. São Paulo: Senac, 2001.

BERNADINO, Eliane de Castro. et al. Marketing de varejo. Rio de Janeiro: Editora FGV, 2004.

BISSOLI, M. A. M. A. Planejamento turístico municipal com suporte em sistemas de informações. São Paulo: Futura, 1999.

BONALD, Olímpio. Planejamento e organização do turismo: conceitos básicos. 2. ed. Recife: FASA, 1984.

BOONE, L. E; KURTZ, D. L. Marketing contemporâneo. 8. ed. Rio de Janeiro: LTC Editora, 1998.

BOULLÓN, R. C. Planificación del espacio turistico. 3. ed. México: Editorial Trillas, 1997.

BOYER, Marc. L'invention du tourism. Triste: Découvertes Gallimard, 1996. 
MIGUEL Giancarlos Francisco; SILVEIRA Ricardo Boeing da Vai pra onde? Análise do composto mercadológico de um destino turístico em Santa Catarina. Revista Brasileira de Pesquisa em Turismo. v. 2, n. 3, p. 54-89,

ISSN: 1982-6125 nov. 2008.

CASTELLI, Geraldo. Turismo de marketing: uma abordagem hoteleira. Porto Alegre: Sulina, 1984.

COOPER, C. Turismo: princípios e práticas. Porto Alegre: Bookmann, 2001.

CIRIOLANO, Luzia Neide M. T. Do local ao global: o turismo litorâneo cearence. Coleção Turismo. Campinas: Papirus, 1998.

COSTA VERDE MAR: A rota do sol catarinense. Publicação da Associação dos Municípios da Foz do Rio Itajaí - AMFRI. Ano 1, 2006.

CHURCHILL, G. A; PETER, J. P. Marketing: criando valor para os clientes. 2. ed. São Paulo: Saraiva, 2000.

Saraiva, 2003.

Marketing: criando valor para os clientes. 3. ed. São Paulo:

CUNHA, Licínio. Economia e política do turismo. Alfagide, Portugal: McGraw-Hill, 1997.

DAVIDSON, Thomas Lea. O que são viagens e turismo: constituem de fato um setor? São Paulo: Senac, 2001.

DE LA TORRE, O. El turismo, fenômeno social. México: Fondo de Cultura Econômica, 1992.

DIAS, Reinaldo; AGUIAR, Marina. Fundamentos do turismo. Campinas, SP: Alínea, 2002.

GIL, Antonio Carlos. Métodos e técnicas de pesquisa social. 5. ed. São Paulo: Atlas, 1999.

GOELDNER, C. R; RITCHIE, J. R. B; MCINTOSH, R. W. Turismo: princípios, práticas e filosofias. 8. ed. Porto Alegre: Bookman, 2002.

IGNARRA, Luiz Renato. Fundamento do turismo. São Paulo: Pioneira, 1999.

KEEGAN, W. J; GREEN, M. Principios de marketing global. 2. ed. São Paulo: Saraiva, 2000.

KOTABE, Masaaki; HELSEN, Kristian. Administração de marketing global. São Paulo: Atlas, 2000.

KOTLER, Philip. Administração de marketing: análise, planejamento, implementação e controle. 5. ed. São Paulo: Atlas, 1998.

Administração de marketing. 10. ed. Rio de Janeiro: Prentice Hall do Brasil, 2000. 
MIGUEL Giancarlos Francisco; SILVEIRA Ricardo Boeing da Vai pra onde? Análise do composto mercadológico de um destino turístico em Santa Catarina. Revista Brasileira de Pesquisa em Turismo. v. 2, n. 3, p. 54-89,

ISSN: 1982-6125 nov. 2008.

LAGE, Beatriz Helena Gelas; MILONE, Paulo César. Economia do turismo. 4. ed. Campinas, SP: Papirus, 1999.

. Turismo: teoria e prática. São Paulo: Atlas, 2000.

LEMOS, Leandro. O valor turístico na economia da sustentabilidade. São Paulo: Aleph, 2005.

LUHRMAN, D.; BENOT, J. Tourism satellite account wins wide acclaim. Conference on the Measurementof the Economic Impact of Tourism. WTC World Tourism Organization. Nice, France, 17 jul. 1999.

LUNDBERG, V. N. R. The tourism business. $6^{\text {th }}$ ed. New York, 1990.

MATTAR, Fauze Najib. Pesquisa de marketing. São Paulo: Atlas, vol. 1-2, 1999.

MCDANIEL, Carl D. et al. Pesquisa de marketing. São Paulo: Thomson, 2003.

MIDDLETON, Victor T.C. Marketing de turismo: teoria e prática. 3. ed. São Paulo: Campus, 2002.

MOTA, Keila Cristina Nicolau. Marketing turístico: promovendo uma atividade sazonal. São Paulo: Atlas, 2001.

O'CONNOR, P. Distribuição da informação eletrônica em turismo e hotelaria. Porto Alegre: Bookman, 2001.

OLIVEIRA, Antônio Pereira. Turismo e desenvolvimento: planejamento e organização. 3. ed. São Paulo: Atlas, 2001.

RUSCHMANN, Doris van de Meene. Marketing turístico: um enfoque promocional. 4. ed. Campinas/SP: Papirus, 1999.

SANDHUSEN, Richard. Marketing básico. São Paulo: Saraiva, 1998.

. Marketing básico. 2. ed. São Paulo: Saraiva, 2003.

THEOBALD, W. F. Turismo Global. São Paulo: Editora SENAC, 2001.

VAZ, Gil Nuno. Marketing turístico: receptivo e emissivo. São Paulo: Pioneira, 1999.

WAHAB, S. A. Introdução à administração do turismo. 3. ed. São Paulo: Pioneira, 1991. 
MIGUEL Giancarlos Francisco; SILVEIRA Ricardo Boeing da Vai pra onde? Análise do composto mercadológico de um destino turístico em Santa Catarina. Revista Brasileira de Pesquisa em Turismo. v. 2, n. 3, p. 54-89,

ISSN: 1982-6125 nov. 2008

\section{Bibliografia}

BOOGMANN, I. M. Marketing de relacionamento: estratégias de fidelização e suas implicações financeiras. São Paulo: Nobel, 2000.

CERVO, A. L; BERVIAN, P. A. Metodologia científica. Rio de Janeiro: Prentice Hall, 2005.

COBRA, M. Administração de marketing no Brasil. São Paulo: Cobra Editora \& Marketing. 2003.

Marketing competitivo. São Paulo: Atlas, 1993.

DIAS, Sérgio Roberto. et al. Gestão de marketing. São Paulo: Saraiva, 2003.

DRUCKER, P. F. Administração de organizações sem fins lucrativos: princípios e práticas. São Paulo: Thomson, 2002.

GIL, Antonio Carlos. Técnicas de pesquisa em economia e elaboração de monografias. São Paulo: Atlas, 2000.

HALLOWAY, J. C; PLANT, R. V. Mercadotécnica turística. México: Diana, 1992.

KOTLER, Philip. Marketing para o século XXI. 4. ed. São Paulo: Atlas, 1999.

KOTLER, Philip; ARMSTRONG, Gary. Princípios de marketing. Rio de Janeiro: Prentice -Hall do Brasil, 1993.

LAKATOS, E. M; MARCONI, M. A. Metodologia científica. São Paulo: Atlas, 1991.

LAMB, C. W. et al. Princípios de marketing. São Paulo: Thomson, 2004.

LAS CASAS, Alexandre Luzzi. Marketing: conceitos, exercícios e casos. 4. ed. São Paulo: Atlas, 1997.

Marketing de serviços. 3. ed. São Paulo: Atlas, 2002.

LIMA, M. C. Monografia: a engenharia da produção acadêmica. São Paulo: Saraiva, 2004.

MANZO, J. M. C. Marketing: uma ferramenta para o desenvolvimento. Rio de Janeiro: Livros Técnicos e Científicos Editora, 1996.

MARCHIN, C. A. Marketing y turismo: gestión turística. Madrid: Editorial Sintesis, 1993. 
MIGUEL Giancarlos Francisco; SILVEIRA Ricardo Boeing da Vai pra onde? Análise do composto mercadológico de um destino turístico em Santa Catarina. Revista Brasileira de Pesquisa em Turismo. v. 2, n. 3, p. 54-89,

ISSN: $1982-6125$ nov. 2008

MATTAR, Fauze Najib. Pesquisa de marketing: metodologia, planejamento. Volume 1. São Paulo: Atlas, 1996.

MCKENA, R. O novo marketing. In: HSM Management, N.1, p. 124-127, Março/Abril 1997.

. Marketing de relacionamento. Rio de Janeiro: Campus, 2000.

MORRIS, M. J. Iniciando uma pequena empresa com sucesso. São Paulo: Makron Books, 1991.

NICKELS, W. G; WOOD, M. B. Marketing: relacionamentos, qualidade, valor. Rio de Janeiro: LTC Editora, 1999.

PINHEIRO, R. M. et al. Comportamento do consumidor e pesquisa de mercado. Rio de Janeiro: Editora FGV, 2004.

PORTO BELO. Portal Porto Belo Online 2007. Disponível em: http://www.portobelo.com.br/index.php?option=com_content\&task=view\&id= 48\&Itemid=101. Acesso em: 13 nov 2007.

RICHERS, Raimar. Marketing: uma visão brasileira. São Paulo: Negócios, 2000.

SIMÕES, Roberto. Marketing básico. São Paulo: Saraiva, 1985.

STANTON, Willian J. et al. Marketing. São Paulo: Makron Books, 2001.

TRIGUEIRO, C. M. Marketing e turismo: como planejar e administrar o marketing turístico para uma localidade. Rio de Janeiro: Qualitymark, 2001. 